\title{
Pathogenic Variation and Occurrence of Multiple Resistance-Breaking Rice yellow mottle virus Strains in Tanzania
}

\author{
Judith Hubert*, Herman J. F. Lyimo, Ashura Luzi-Kihupi \\ Department of Crop Science and Horticulture, Sokoine University of Agriculture, Morogoro, Tanzania \\ Email: *hubertjudith@yahoo.com
}

How to cite this paper: Hubert, J., Lyimo, H.J.F. and Luzi-Kihupi, A. (2017) Pathogenic Variation and Occurrence of Multiple Resistance-Breaking Rice yellow mottle virus Strains in Tanzania. American Journal of Plant Sciences, 8, 1820-1841.

https://doi.org/10.4236/ajps.2017.88124

Received: May 24, 2017

Accepted: July 7, 2017

Published: July 10, 2017

Copyright ( 92017 by authors and Scientific Research Publishing Inc. This work is licensed under the Creative Commons Attribution International License (CC BY 4.0).

http://creativecommons.org/licenses/by/4.0/

\begin{abstract}
Rice yellow mottle virus (RYMV) is a major biotic constraint for rice production in Africa. The resistance-breaking ability of Tanzanian RYMV strains and phylotypes (S4lm (Tz526), S4lv (Tz516), S4ug (Tz508), S5 (Tz429, Tz445), S6c (Tz486) and S6w (Tz539)) were tested by inoculating rice cultivars with $R Y M V 1$ resistant alleles (Gigante (rymvl-2), Tog12387 (rymvl-3), Tog5681 (rymvl-3), Tog5438 (rymv1-4), Tog5672 (rymv1-4+rymv2) and Tog5674 (rymv 1-5)) in a screen house. The results revealed multiple resistance-breaking strains and phylotypes on resistant cultivars Gigante, Tog12387, Tog5438 and Tog5681. However, the resistance breakdown was highly variable depending on the strain used, and disease severity ranged from $11 \%-75.3 \%$. The virulence potential of RYMV phylotype S4lm (Tz526) was similar to phylotype S6w (Tz539). The impact of strains and phylotypes on yield and its components in rice cultivars revealed highly significant differences $(P \leq 0.001)$. The lowest percent plant height reduction (2.8\%), number of tillers per plant (2.5\%), 1000 grain weight $(2.7 \%)$, spikelet sterility (3.5\%) and yield (5\%) was recorded in rice cultivar Gigante inoculated with RYMV phylotype S6c (Tz486). Phylotype S6c (Tz486) despite being less virulent compared to other strains, its virus titer in rice cultivar Gigante (1.833) was higher than S5 (Tz429, Tz445) inoculated on Tog5674 $(0.171,0.207)$ and S6w (Tz539) inoculated on Tog5681 (0.283). The resistant-breaking strain S5 (Tz445) multiplied in resistant rice cultivar Tog5674 without inducing visible symptoms but showed positive reaction to ELISA with low virus titer. The strain S5 overcame wide range of resistant alleles including rymv1-2, rymv1-3, rymv1-4 and rymv1-5 resistance, with exception of rymv1-4 + rymv2. The current results gave a new perspective for future identification of resistance-breaking mutations through sequencing of the RYMV genome in infected rice cultivars and mutagenesis of an infectious viral clone useful for future RYMV resistant breeding programs.
\end{abstract}




\section{Keywords}

Pathogenic Variation, Virulence, Multiple Resistance-Breaking, RYMV Strains, Yield Losses, Tanzania

\section{Introduction}

High genetic diversity of RYMV and evolution of resistant-breaking strains and phylotypes are challenges in developing durable disease resistant varieties. Management of RYMV has relied on the use of resistant varieties. Insect vector control and prophylactic measures such as high surveillance of seedbeds, fields and weed reservoirs are also used for management of RYMV despite time-consuming and variable efficiency [1] [2]. The resistance of rice plants to RYMV is controlled by the recessive gene $R Y M V 1$ [3], located on chromosome 4 [4] and encodes the isoform of the eukaryotic translation initiation factor $4 \mathrm{G}$ (eIF (iso) 4G1) [5] but RYMV is able to evolve fast. Generally, most of resistance sources to RYMV obtained from Oryza glaberrima. Several highly resistant varieties with known genes of resistant to RYMV have been identified that include rice cultivars Gigante (rymvl-2) [3], Tog12387 (rymvl-3) [6], Tog5681 (rymvl-3) [4], Tog5438 (rymvl.4), Tog5672 (rymv1-4+rymv2) and Tog5674 (rymvl-5) [7]. Resistance conferred by $R Y M V 2$ and $R Y M V 3$ genes have currently been identified on Oryza glaberrima Tog7291 and Tog5307, respectively [2] [8]. Partial genetic resistance quantitative trait locus (QTLs) which is polygenic has been reported to be widespread in Oryza sativa subsp. japonica cultivars such as Azucena [9]. The resistance QTLs has been reported to be characterized by a delay in symptom expression, low virus accumulation and limited yield loss under field condition [10]. The resistance has been estimated and measured the area under disease progress curve by assessing the disease severity at different number of days after inoculation [11].

The RYMV disease is characterized by mottling and yellowing symptoms, stunted growth, reduction of tiller formation and grain sterility [12]. Rice yellow mottle virus disease may also cause complete crop failure that resulted from incomplete panicle emergence and necrosis. Previous studies reported the significant yield losses ranging from 20\% - 100\% caused by RYMV pathogen. The virus can be detected by symptoms and direct antibody sandwich enzyme-linked immunosorbent assay (DAS-ELISA) using polyclonal antibodies [13]. Disease severity refers as effect of the virus on an individual rice plant covered by symptoms and measured either by necrosis or stunting and decrease in plant height that can be used to gauge yield losses [12].

Diverse groups of Rice yellow mottle virus strains are widely distributed in Tanzania [14] [15] [16] [17]. The strain S5 is restricted in Morogoro region, while S4 and S6 are widely spread throughout the country [14] [16]. Rice (Oryza sativa L.) is one of the major staple foods ranking second after wheat worldwide [18]. In Tanzania, rice is the second most important staple cereal grain after ma- 
ize. The smallholder farmers depend on rice both for food security and cash [19]. Despite rice being an important food crop in Tanzania, productivity has remained low 1 - $1.5 \mathrm{t} \cdot \mathrm{ha}^{-1}$ compared to over $5 \mathrm{t} \cdot \mathrm{ha}^{-1}$ reported in Asia countries [18] [20]. Rice yellow mottle virus is a major biotic constraint for rice production in Africa [21] [22].

High level of RYMV genetic diversity have accelerated emergence of new virulent strains which are capable for overcoming resistance of cultivated rice plants. The existence of high genetic diversity of RYMV in Tanzania [14] [16], may be associated with emergence of pathogen virulence and resistant-breaking strains. Such high level of pathogen adaptability has seriously affected efforts of breeding RYMV disease resistance varieties. The molecular basis of breaking resistance conferred by $R Y M V 1$ gene has been studied for the alleles rymv1-2 and rymv1-3 [23] [24] and resistance breakdown associated with emerging RYMV phylotypes has also been observed under screen house conditions [25] [26].

The highly resistant rice cultivar Gigante has been reported to be effective against range of different RYMV strains from Central and West Africa [3] [26], the phenomena which recently have also been observed in Uganda [27]. In Tanzania, RYMV strain S6 (Tz209) has been reported to break the resistance of rice cultivar Gigante [23]. The resistance of Gigante has also been reported to be broken down by RYMV strains from various geographic areas [25] [26] [28]. Furthermore, the occurrence of resistance-breaking of West and Central African RYMV strains for highly resistant rice (Oryza spp.) cultivars Gigante (rymvl-2) and Tog5681 (rymvl-3) has also been reported [24] [26] [29].

Selection and breeding for disease resistant varieties is considered as the best means for control of RYMV disease and have successfully been done in several countries in Africa [6] [7] [27] [30] [31] [32]. But such resistant varieties were developed using only a single RYMV strain which does not necessarily protect rice plant from other strains. The development of resistant varieties requires clear understanding of genetic variability of host and pathogen and its impact on the interaction between them. Cultivars with stable genes of resistance are likely to be selected for cultivar improvement. However, natural occurrence of the strains is not enough to evaluate durability of resistance to RYMV; it should rather be assessed using mechanical inoculation of commonly occurring strain [25].

Identification of resistant-breaking RYMV strains in rice cultivars with $R Y M V 1$ resistant genes in Tanzania will enable identification of suitable resistant genotypes to improve local rice cultivars. Lack of information on the distribution of virulent strains and their reaction on differential rice genotypes, slows the process of breeding for RYMV resistance in Tanzania. The purpose of this study, therefore, was (i) to determine the pathogenic variation of Tanzanian RYMV strains and phylotypes against rice cultivars with known resistant genes and (ii) to assess the virulence and multiple resistant-breaking ability of RYMV strains and phylotypes on highly resistant cultivars as well as partially resistant and susceptible rice varieties and their effect on yield. 


\section{Materials and Methods}

\subsection{Sources of Rice yellow mottle virus Strains and phylotypes}

Infected leaf samples with typical symptoms of different RYMV strains and phylotypes used in this study are shown in Table 1. The infected rice samples were kept in nylon and paper bags and transported to the laboratory at Sokoine university of Agricuture, Morogoro and stored in the refrigerator at $-20^{\circ} \mathrm{C}$ for further use. Three preservation methods (thick plastic bags (Zip lock), small brown paper envelopes and vacuum-sealed plastic bags) were used to reduce the chances of loss of RYMV viability.

\subsection{Sources of Resistant Rice Genotypes}

The sources of rice genotypes with known resistant genes used to screen Tanzanian RYMV strains and phylotypes are shown in Table 2.

\subsection{Evaluation of the Pathogenic Variation of Different RYMV Strains}

The resistance-breaking ability of different RYMV strains and phylotypes from

Table 1. Rice yellow mottle virus strains and phylotypes used in this study.

\begin{tabular}{cccccc}
\hline Isolate & Region & District & Date & Strain & Reference \\
\hline Tz516 & Arusha & Monduli & 2014 & S4lv & Hubert et al. [17] \\
Tz508 & Kilimanjaro & Moshi & 2014 & S4ug & Hubert et al. [17] \\
Tz526 & Morogoro & Kilombero & 2013 & S4lm & Hubert et al. [17] \\
Tz429 & Morogoro & Kilombero & 2013 & S5 & Hubert et al. [17] \\
Tz445 & Morogoro & Ulanga & 2014 & S5 & Hubert et al. [17] \\
Tz486 & Morogoro & Ulanga & 2014 & S6c & Hubert et al. [17] \\
Tz539 & Morogoro & Kilombero & 2013 & S6w & Hubert et al. [17] \\
\hline
\end{tabular}

S4lv $=$ Strain 4-Lake Victoria, S4ug $=$ Strain 4-Uganda, S4lm $=$ Strain 4-Lake Malawi, S6c $=$ Strain 6-coast area, $\mathrm{S} 6 \mathrm{w}=$ Strain 6 -wide, $\mathrm{Tz}=$ Tanzania.

Table 2. Resistant rice genotypes, associated genes and source.

\begin{tabular}{cccc}
\hline Rice genotype & Resistant genes & Sources of seeds & Reference \\
\hline Azucena (Partial R.) & QTLs & IRD, France & Albar et al. [9] \\
IR64 (S. control) & $r y m v 1-1$ & IRD, France & Ndjiondjop et al. [3] \\
Gigante & $r y m v 1-2$ & IRD, France & Ndjiondjop et al. [3] \\
Tog12387 & rymvl-3 & AfricaRice & Jaw [6] \\
Tog5681 & rymvl-3 & IRD, France & Albar et al. [4] \\
Tog5438 & rymvl-4 & IRD, France & Thiemélé et al. [7] \\
Tog5672 & rymvl-4+ rymv2 & IRD, France & Thiemélé et al. [7] \\
Tog5674 & rymvl-5 & IRD, France & Thiemélé et al. [7] \\
SARO-5 (S. control) & Unknown & SUA & Msomba et al. [33] \\
\hline
\end{tabular}

SUA = Sokoine University of Agriculture, IRD = French National Research Institute for Sustainable Development, QTLs = Quantitative trait locus, $\mathrm{S}=$ Susceptible, $\mathrm{R}=$ Resistant. 
Tanzania was evaluated on rice cultivars with $R Y M V 1$ gene. The reaction of the known rice resistant cultivars Gigante (rymv1-2), Tog12387 (rymv1-3), Tog 5681 (rymv1-3), Tog5438 (rymv1-4), Tog 5672 (rymv1-4+rymv2) and Tog 5674 (rymv1-5) against RYMV Tanzanian strains and phylotypes was tested in a screen house. Split-plot design with three replications was adopted. The strains were considered as the main-plot and the cultivar as the sub-plot. Partially resistant (Azucena), and susceptible local variety (SARO-5) and (IR64) were included as controls.

\subsection{Planting and Seed Establishment}

Sixty seeds of each variety were planted in each replication (2 seeds/hole) in plastic trays, measuring $48 \mathrm{~cm}$ length, $34 \mathrm{~cm}$ width and $9.5 \mathrm{~cm}$ depth filled with $10 \mathrm{~kg}$ of sterilized forest soil. The soil was mixed with $\mathrm{N}: \mathrm{P}: \mathrm{K}(15: 15: 15)$ at a rate of $8 \mathrm{~g} /$ tray before sowing of seeds followed by split application of Urea $(8 \mathrm{~g}) 7$ days after inoculation (DAI) and at early stage of flowering. Thirty plants of each cultivar in each replication were used. Trays were constantly irrigated with fresh tap water on the daily basis until maturity.

\subsection{Inoculation and Disease Assessment}

Inoculum was prepared by grinding infected rice leaves using a mortar and pesthe in phosphate buffer saline with $0.5 \%$ Tween-20 (PBST 1X) at a ratio of 1:10 $\mathrm{w} / \mathrm{v}$ [13]. Nine milliliter of PBST $1 \mathrm{X}$ were added to 0.9 grams of ground infected leaves of each RYMV strain and/or phylotype to prepare inoculum which was used to inoculate 90 rice seedlings. Control plants were inoculated with plain PBST 1X. Rice seedlings were inoculated with each of the following RYMV strain or phylotype: S4lm, S4lv, S4ug, S5, S6c and S6w which coded Tz526, Tz516, Tz508, (Tz429, Tz445), Tz486 and Tz539, respectively. Inoculation was done 15 days after sowing (DAS). The last expanded leaves were inoculated by scratching the leaves using sand paper and then rubbed with cotton to inoculate the virus. Observations of RYMV symptoms were done weekly, up to 42 days after inoculation. However, inoculated rice plants were monitored daily up to maturity in order to evaluate the resistant breaking strains variability.

Disease severity was assessed on individual plant basis using a rating scale of 1 - 9 [34]; where 1 represented no symptoms, 3 = Leaves green, but with sparse disease or streaks, and less than $5 \%$ reduction in height, $5=$ leaves green or pale green with mottling, $6 \%$ - 25\% height reduction and flowering slightly delayed, 7 $=$ leaves pale yellow or yellow, $26 \%$ - 75\% height reduction and flowering delayed, $9=$ leaves yellow or orange, more than $75 \%$ height reduction, no flowering and some plants dead. The reaction of RYMV disease to rice cultivars was done using a modified scale developed by Zouzou et al. [35], whereas values from 1 to 1.5 were given a score of $1=$ highly resistant, $1.6-4.5$ were assigned a score of 3 = resistant, 4.6 - 6.5 were rated as $5=$ moderately resistant, $6.6-8.5$ as 7 = susceptible, and 8.6 - 9 as $9=$ highly susceptible. Scores above three were considered as virulent strains or phylotypes [1]. Disease incidence (I) and sever- 
ity (S) were calculated according to the procedures described by Finninsa [36] as follows: $I=\left(n_{5}+n_{7}+n_{9}\right) * 100 /\left(n_{1}+n_{3}+n_{5}+n_{7}+n_{9}\right)$ and $S=\left(\left(n_{1} * 1\right)+\left(n_{3} * 3\right)+\left(n_{5} * 5\right)+\left(n_{7} * 7\right)+\left(n_{9} * 9\right)\right) * 100 /\left(n_{1}+n_{3}+n_{5}+n_{7}+n_{9}\right) * 9$ where $n_{1}, n_{3}, n_{5}, n_{7}, n_{9}$ represented the number of leaves scored 1, 3, 5, 7 and 9, respectively.

The resistance-breakdown of each resistant rice cultivar were also compared by evaluating the area under disease progress curve (AUDPC) for each strain with the formula: AUDPC $=\Sigma\left[\left(S_{i+1}+S_{i}\right) / 2\right]\left[t_{i+1}-t_{i}\right] i=1$, where: $S_{i}=$ disease severity at the $i$ th observation and $t_{i}=$ time (days) at the $i$ th observation [37].

\subsection{Immunological Analysis of Rice yellow mottle virus}

The last fully expanded leaf of each rice plant was collected 42 DAI for ELISA test. The rice leaves of each tested rice cultivar that did not show symptoms were also collected separately at 60 DAI for ELISA test.

Direct antibody sandwich enzyme-linked immunosorbent assay (DAS-ELISA) was used to test for the presence of RYMV in leaves harvested from inoculated rice cultivars following procedures described by Pinel et al. [13]. The polyclonal antiserum produced against a Madagascan RYMV strain was used as a primary antibody. The virus titer was considered significant when the optical density (OD) values were two-fold greater than the mean value of the negative control.

\subsection{Effect of RYMV on Yield Components of Resistant Rice Cultivars}

The effect of RYMV strains and phylotypes on the yield components of rice cultivars was evaluated according to procedures developed by Zouzou et al. [35]. Yield components included plant height $(\mathrm{cm})$, the number of tillers per plant and 1000 grain weight $(\mathrm{g})$. The height of the rice plant was determined using a ruler by measuring the aerial part of the shoot from the soil surface to the tip of a long panicle. To determine the number of tillers per plant, all tillers for thirty individual plants per tray in each studied cultivar were counted and summed up to obtain the average number of tillers per plant. The number of filled and unfilled grains per panicle was also counted for assessment of spikelet sterility. Yield loss per panicle was determined as indicated in the formula below.

$\mathrm{Y} / \mathrm{p}=\frac{\text { Mean yield of filled grains of non-inoculated }- \text { Mean yield of filled grains of inoculated }}{\text { Mean yield of filled grains of non-inoculated }} \times 100$ where: $\mathrm{Y} / \mathrm{p}=$ yield loss per panicle $(\%)$

Data obtained were used to assess both inoculated and non-inoculated seedlings of each cultivar and thus, the impact of the RYMV disease on growth of the rice plants. Mean values were calculated and the impact of the disease was assessed using the following formula:

$$
\text { Impact of } \operatorname{RYMV}(\%)=(\mathrm{Ni}-\mathrm{I}) \times 100 / \mathrm{Ni} \quad[35]
$$

where: $\mathrm{Ni}=$ mean values on the seedlings not inoculated

$\mathrm{I}=$ mean values on the seedlings inoculated 
Spikelet sterility $(\%)=\frac{\text { Number of unfilled grains }}{\text { Number of unfilled grains }+ \text { Number of filled grains }} \times 100$

\subsection{Data Analysis and Statistical Model}

Rice yellow mottle virus disease severity data were analyzed using GenStat Software Package (14 ${ }^{\text {th }}$ edition). Prior analysis data were arcsine transformed [38]. A constant value (0.5) was added to each observation prior arcsine transformation as recommended by McDonald [39]. Dunkan's Multiple Range Test at $P \leq 0.05$ was used to compare treatment means.

The following statistical model was used for analysis: $Y_{i j}=\mu+C_{i}+R_{j}+C R_{i j}+E_{i j}$ where $Y_{i j}=$ Response of variables investigated, $\mu=$ General mean, $C_{i}=i$ th effect of cultivars, $R_{j}=j$ th effect of RYMV strains, $C R_{i j}=$ Interaction due to cultivars and RYMV strains, $E_{i j}=$ Experimental error.

\section{Results}

\subsection{Pathogenic Variation of Different Strains and Phylotypes}

The resistance-breaking ability of Tanzanian RYMV strains and phylotypes were evaluated using rice differential cultivars with $R Y M V 1$ resistance gene. Disease progress and disease reaction classes are shown in Table 3 and Figure 1. The

Table 3. Incidence and severity of Rice yellow mottle virus strains and phylotypes on rice cultivars 42 days after inoculation in the screen house.

\begin{tabular}{|c|c|c|c|c|c|c|c|c|c|c|c|c|c|c|}
\hline \multirow{2}{*}{$\begin{array}{l}\text { Rice } \\
\text { cultivar }\end{array}$} & \multicolumn{7}{|c|}{ Incidence (\%) } & \multicolumn{7}{|c|}{ Severity (\%) } \\
\hline & $\begin{array}{c}\text { S4lm } \\
\text { (Tz526) }\end{array}$ & $\begin{array}{c}\text { S4lv } \\
(\text { Tz516) }\end{array}$ & $\begin{array}{c}\text { S4ug } \\
\text { (Tz508) }\end{array}$ & $\begin{array}{c}\text { S5 } \\
(\mathrm{Tz} 445)\end{array}$ & $\begin{array}{c}\text { S5 } \\
(\mathrm{Tz} 429)\end{array}$ & $\begin{array}{c}\text { S6c } \\
(\mathrm{Tz} 486)\end{array}$ & $\begin{array}{c}\text { S6w } \\
(\text { Tzz539) }\end{array}$ & $\begin{array}{c}\text { S4lm } \\
(\text { Tz526) }\end{array}$ & $\begin{array}{c}\text { S4lv } \\
(\text { Tz516) }\end{array}$ & $\begin{array}{c}\text { S4ug } \\
\text { (Tz508) }\end{array}$ & $\begin{array}{c}\text { S5 } \\
(\mathrm{Tz} 445)\end{array}$ & $\begin{array}{c}\text { S5 } \\
(\mathrm{Tz} 429)\end{array}$ & $\begin{array}{c}\text { S6c } \\
(\mathrm{Tz} 486)\end{array}$ & $\begin{array}{c}\text { S6w } \\
(\text { Tz539) }\end{array}$ \\
\hline Azucena & $19.6 \mathrm{bc}$ & $8.5 \mathrm{ab}$ & $3.4 \mathrm{a}$ & $54.6 \mathrm{~d}$ & $45 \mathrm{~d}$ & $1.1 \mathrm{a}$ & $35.5 \mathrm{c}$ & $31.3 \mathrm{c}$ & $19.5 \mathrm{~b}$ & $17 \mathrm{~b}$ & $50 \mathrm{c}$ & $51.3 \mathrm{~d}$ & $15.9 \mathrm{c}$ & $37.5 c$ \\
\hline Gigante & $10.6 \mathrm{ab}$ & $17.8 \mathrm{bc}$ & $2.2 \mathrm{a}$ & $47.1 \mathrm{c}$ & $38.8 \mathrm{~b}$ & $1.3 \mathrm{a}$ & $17 \mathrm{~b}$ & $19.4 \mathrm{a}$ & $24.7 \mathrm{bc}$ & $13.8 \mathrm{a}$ & $52 \mathrm{~d}$ & $50.8 \mathrm{c}$ & $13.3 \mathrm{~b}$ & $25.8 \mathrm{~b}$ \\
\hline Tog12387 & $45.5 \mathrm{~d}$ & $47.2 \mathrm{~d}$ & $33.4 \mathrm{c}$ & $100 f$ & $83.3 \mathrm{f}$ & $22.8 \mathrm{~b}$ & $54.7 \mathrm{~d}$ & $50 \mathrm{e}$ & $46.1 \mathrm{~d}$ & $41.4 \mathrm{~d}$ & $75.3 \mathrm{f}$ & $74 \mathrm{f}$ & $38.3 \mathrm{~d}$ & $51 \mathrm{~d}$ \\
\hline Tog5438 & $48.9 \mathrm{~d}$ & $18.6 \mathrm{c}$ & $8.1 \mathrm{~b}$ & $85.8 \mathrm{e}$ & $80.7 \mathrm{e}$ & $1 \mathrm{a}$ & $38.3 \mathrm{c}$ & $40.5 \mathrm{~d}$ & $27.9 \mathrm{c}$ & $22.1 \mathrm{c}$ & $73 \mathrm{e}$ & $71.1 \mathrm{e}$ & $13.9 \mathrm{~b}$ & $39.5 \mathrm{c}$ \\
\hline Tog5672 & $0.5 \mathrm{a}$ & $0.5 \mathrm{a}$ & $0.5 \mathrm{a}$ & $0.5 \mathrm{a}$ & $0.5 \mathrm{a}$ & $0.5 \mathrm{a}$ & $0.5 \mathrm{a}$ & $11.1 \mathrm{a}$ & $11.1 \mathrm{a}$ & $11.1 \mathrm{a}$ & $11.1 \mathrm{a}$ & $11.1 \mathrm{a}$ & $11.1 \mathrm{a}$ & $11.1 \mathrm{a}$ \\
\hline Tog5674 & $0.5 \mathrm{a}$ & $0.5 \mathrm{a}$ & $0.5 \mathrm{a}$ & $0.5 \mathrm{a}$ & $0.5 \mathrm{a}$ & $0.5 \mathrm{a}$ & $0.5 \mathrm{a}$ & $11.1 \mathrm{ab}$ & $11.1 \mathrm{a}$ & $11.1 \mathrm{a}$ & $11.1 \mathrm{a}$ & $11.1 \mathrm{a}$ & $11.1 \mathrm{a}$ & $11.1 \mathrm{a}$ \\
\hline Tog5681 & $26.2 \mathrm{c}$ & $0.5 \mathrm{a}$ & $0.5 \mathrm{a}$ & $40.9 \mathrm{~b}$ & $40.6 c$ & $0.5 \mathrm{a}$ & $13 \mathrm{~b}$ & $32.2 \mathrm{c}$ & $11.1 \mathrm{a}$ & $11.1 \mathrm{a}$ & $38.2 \mathrm{~b}$ & $38 \mathrm{~b}$ & $11.1 \mathrm{a}$ & $29 \mathrm{~b}$ \\
\hline \multicolumn{15}{|l|}{ S. control } \\
\hline IR64 & $80.6 \mathrm{e}$ & $77.6 \mathrm{e}$ & $65.1 \mathrm{~d}$ & $100 \mathrm{f}$ & $100 \mathrm{~g}$ & $68.7 \mathrm{c}$ & $72.4 \mathrm{e}$ & $63.2 \mathrm{f}$ & $62 \mathrm{e}$ & $59.2 \mathrm{e}$ & $80.4 \mathrm{~g}$ & $82 \mathrm{~g}$ & $57.1 \mathrm{e}$ & $64.8 \mathrm{e}$ \\
\hline SARO-5 & $100 \mathrm{f}$ & $100 \mathrm{f}$ & $95 \mathrm{e}$ & $100 \mathrm{f}$ & $100 \mathrm{~g}$ & $83.7 \mathrm{~d}$ & $100.5 \mathrm{f}$ & $84.2 \mathrm{~g}$ & $80.8 \mathrm{f}$ & $79.5 \mathrm{f}$ & 93.7h & $95.4 \mathrm{~h}$ & $75.4 \mathrm{f}$ & $85 \mathrm{f}$ \\
\hline GM & 37 & 30.2 & 23.2 & 59 & 54.5 & 20 & 36.9 & 38.1 & 32.7 & 29.6 & 53.9 & 53.9 & 27.5 & 39.4 \\
\hline F test & $* * *$ & $* * *$ & $* * *$ & $* * *$ & $* * *$ & $* * *$ & $* * *$ & $* * *$ & $* * *$ & $* * *$ & $* * *$ & $* * *$ & $* * *$ & $* * *$ \\
\hline LSD 5\% & 10.23 & 9.29 & 2.84 & 1.56 & 0.9 & 1.31 & 9.5 & 8.27 & 7.56 & 3.06 & 0.38 & 0.21 & 1.1 & 7.32 \\
\hline CV\% & 16 & 17.8 & 7.1 & 1.5 & 1 & 3.8 & 14.9 & 12.5 & 13.3 & 6 & 0.4 & 0.2 & 2.3 & 10.7 \\
\hline
\end{tabular}

*Values are means of three replicates. Numbers followed by the same letter in a column are not significantly different at $P=0.05$, using Duncan's Multiple Range Test. ${ }^{* *}=$ Highly significantly different $(P<0.001), \mathrm{S}=$ Susceptible, $\mathrm{GM}=$ Grand mean. 


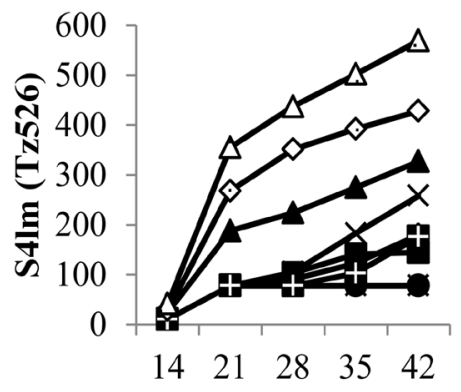

Days after inoculation

(a)

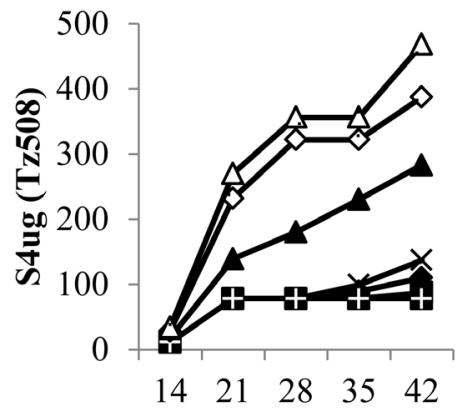

Days after inoculation

(c)

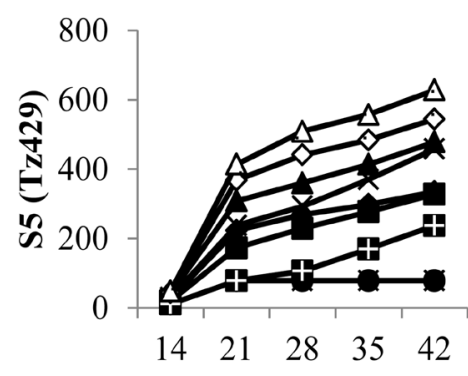

Days after inoculation

(e)

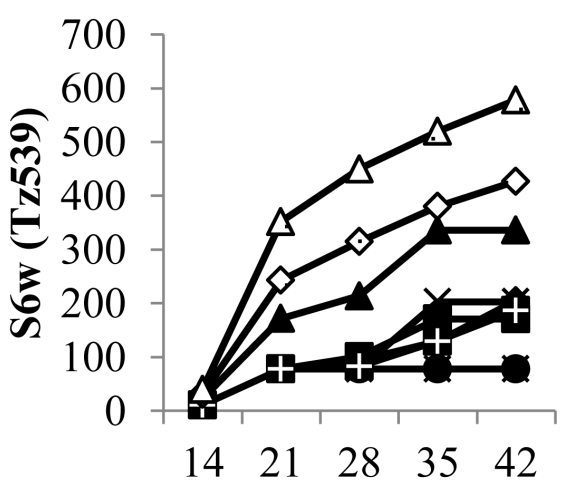

Days after inoculation

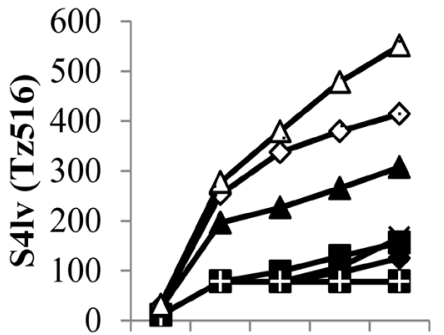

$\begin{array}{lllll}14 & 21 & 28 & 35 & 42\end{array}$

Days after inoculation

(b)

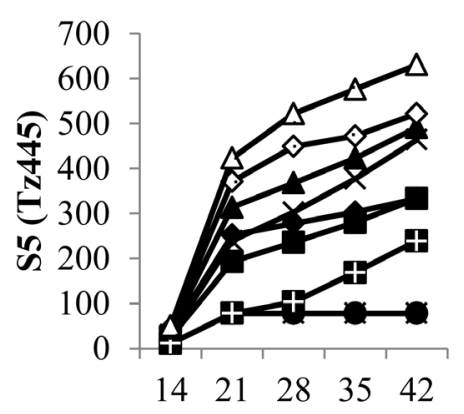

Days after inoculation

(d)

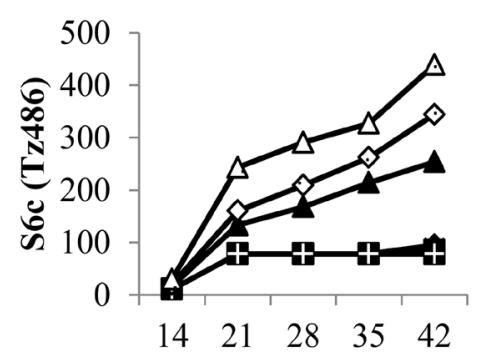

Days after inoculation

(f)

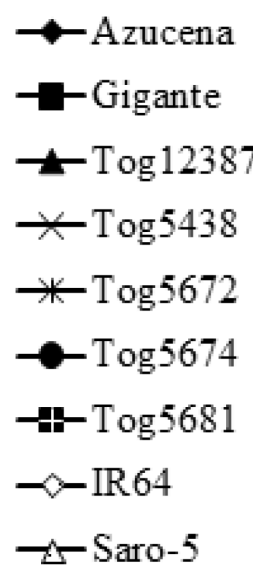

(g)

Figure 1. Area under disease progress curves of inoculated resistant rice cultivars with Rice yellow mottle virus strains or phylotypes. 
results showed multiple resistance-breaking in resistant cultivars Gigante (rymv1-2), Tog12387 (rymv1-3), Tog5681 (rymv1-3) and Tog5438 (rymv1-4) inoculated with Tanzanian RYMV strains S4lm (Tz526), S5 (Tz429, Tz445) and S6w (Tz539) respectively collected in Kilombero and Ulanga districts, Morogoro region (Table 3 and Table 4). Rice yellow mottle virus phylotypes S4lv (Tz516), S4ug (Tz508) and S6c (Tz486) collected in Arusha, Kilimanjaro and Morogoro regions, respectively, overcame the resistance of rice cultivar Gigante (rymv1-2), Tog12387 (rymv1-3) and Tog5438 (rymv1-4). However, all strains and phylotypes (S4lm, S4lv, S4ug, S5, S6c and S6w) gave susceptible reaction on rice cultivars Azucena, Gigante, Tog12387 and Tog5438. Phylotypes S4lv (Tz516), S4ug (Tz508) and S6c (Tz486) were not pathogenic on rice cultivars Tog5672, Tog5674 and Tog5681. The most virulent strain was S5 (Tz445, Tz429) that overcame the resistance in most resistant cultivars, except Tog5672 and Tog5674.

The incidence of RYMV also varied significantly $(P \leq 0.05)$ between rice cultivars, strains and phylotypes (Table 3). The mean incidence of the RYMV disease varied from 20 to $59 \%(P<0.001)$ depending on the level of virulence of strains and phylotypes. The highest incidence of RYMV were recorded in rice cultivars Tog12387 (100\%) and Tog5438 (85.8\%) in which their resistance overcome by strain S5 (Tz445).

Table 4. Rice yellow mottle virus strains and phylotypes disease score and reaction classes on rice cultivars.

\begin{tabular}{|c|c|c|c|c|c|c|c|c|c|c|c|c|c|c|c|}
\hline \multirow{2}{*}{ Genotype } & \multirow{2}{*}{$\begin{array}{l}\text { Resistant } \\
\text { gene }\end{array}$} & \multicolumn{2}{|c|}{ S4lm (Tz526) } & \multicolumn{2}{|c|}{ S4lv (Tz516) } & \multicolumn{2}{|c|}{ S4ug (Tz508) } & \multicolumn{2}{|c|}{ S5 (Tz445) } & \multicolumn{2}{|c|}{ S5 (Tz429) } & \multicolumn{2}{|c|}{ S6c (Tz486) } & \multicolumn{2}{|c|}{ S6w (Tz539) } \\
\hline & & $\mathrm{DSc}$ & DRn & DSc & DRn & $\mathrm{DSc}$ & DRn & DSc & DRn & DSc & DRn & DSc & DRn & $\mathrm{DSc}$ & $\mathrm{DRn}$ \\
\hline Azucena & QTLs & $5.7 \mathrm{c}$ & MR & $4 \mathrm{~b}$ & $\mathrm{R}$ & $3 b$ & $\mathrm{R}$ & $8 c$ & $S$ & $8 \mathrm{c}$ & $S$ & $3 b$ & $\mathrm{R}$ & $6.7 \mathrm{c}$ & S \\
\hline Gigante & $r y m v 1-2$ & $4 \mathrm{~b}$ & $\mathrm{R}$ & $4.6 \mathrm{bc}$ & MR & $1.6 \mathrm{a}$ & $\mathrm{R}$ & $8.1 \mathrm{c}$ & $S$ & $8 c$ & $S$ & $1.6 \mathrm{a}$ & $\mathrm{R}$ & $5 b$ & MR \\
\hline Tog12387 & rymvl-3 & $8 \mathrm{e}$ & $S$ & $7.7 \mathrm{~d}$ & $S$ & $6.8 \mathrm{~d}$ & $S$ & $9 c$ & HS & $8.9 c$ & HS & $6.7 \mathrm{c}$ & S & $8 \mathrm{~d}$ & S \\
\hline $\operatorname{Tog} 5438$ & rymvl-4 & $6.7 \mathrm{~d}$ & S & $5.4 \mathrm{c}$ & MR & $4.6 \mathrm{c}$ & MR & $8.9 \mathrm{c}$ & HS & $8.8 \mathrm{c}$ & HS & $3 b$ & $\mathrm{R}$ & $6.7 \mathrm{c}$ & S \\
\hline $\operatorname{Tog} 5672$ & $\begin{array}{c}r y m v 1-4+r y \\
m v 2\end{array}$ & $1.2 \mathrm{a}$ & HR & $1.2 \mathrm{a}$ & HR & $1.2 \mathrm{a}$ & HR & $1.2 \mathrm{a}$ & $\mathrm{HR}$ & $1.2 \mathrm{a}$ & HR & $1.2 \mathrm{a}$ & $\mathrm{HR}$ & $1.2 \mathrm{a}$ & $\mathrm{HR}$ \\
\hline Tog5674 & rymvl-5 & $1.2 \mathrm{a}$ & HR & $1.2 \mathrm{a}$ & HR & $1.2 \mathrm{a}$ & HR & $1.2 \mathrm{a}$ & HR & $1.2 \mathrm{a}$ & HR & $1.2 \mathrm{a}$ & HR & $1.2 \mathrm{a}$ & HR \\
\hline Tog5681 & rymvl-3 & $5.7 \mathrm{c}$ & MR & $1.2 \mathrm{a}$ & HR & $1.2 \mathrm{a}$ & HR & $6.7 \mathrm{~b}$ & $S$ & $6.7 \mathrm{~b}$ & $S$ & $1.2 \mathrm{a}$ & HR & $5.7 b c$ & MR \\
\hline \multicolumn{16}{|l|}{ S. control } \\
\hline IR64 & rymvl-1 & 8.6ef & HS & 8.6de & HS & $8.4 \mathrm{e}$ & $S$ & $9 c$ & HS & $9 c$ & HS & $8.3 \mathrm{~d}$ & $S$ & $8.6 \mathrm{~d}$ & HS \\
\hline SARO-5 & Unknown & $9 f$ & HS & $9 e$ & HS & $7.5 \mathrm{de}$ & HS & $9 c$ & HS & $9 c$ & HS & $9 \mathrm{~d}$ & HS & $9 \mathrm{~d}$ & HS \\
\hline GM & & \multicolumn{2}{|c|}{5.567} & \multicolumn{2}{|c|}{4.77} & \multicolumn{2}{|c|}{3.94} & \multicolumn{2}{|c|}{6.79} & \multicolumn{2}{|c|}{6.76} & \multicolumn{2}{|c|}{3.91} & \multicolumn{2}{|c|}{5.79} \\
\hline F test & & \multicolumn{2}{|c|}{0.8078} & \multicolumn{2}{|c|}{1.01} & \multicolumn{2}{|c|}{1.01} & \multicolumn{2}{|c|}{1.01} & \multicolumn{2}{|c|}{1.04} & \multicolumn{2}{|c|}{1.177} & \multicolumn{2}{|c|}{1.228} \\
\hline LSD 5\% & & \multicolumn{2}{|c|}{$* * *$} & \multicolumn{2}{|c|}{$* * *$} & \multicolumn{2}{|c|}{$* * *$} & \multicolumn{2}{|c|}{$* * *$} & \multicolumn{2}{|c|}{$* * *$} & \multicolumn{2}{|c|}{$* * *$} & \multicolumn{2}{|c|}{$* * *$} \\
\hline CV\% & & \multicolumn{2}{|c|}{8.4} & \multicolumn{2}{|c|}{12.2} & 14.8 & & & & & & & & 12.3 & \\
\hline
\end{tabular}

*Values are means of three replicates. Numbers followed by the same letter in a column are not significantly different at $P=0.05$, using Duncan's Multiple Range Test. ${ }^{* * *}=$ Highly significantly different $(P<0.001), \mathrm{S}=$ Susceptible, GM $=$ Grand mean, DSc $=$ Disease score, DRn $=$ Disease reaction, $\mathrm{S}=\mathrm{Suscepti}-$ ble. 


\subsection{Rice yellow mottle virus Strains and Phylotypes Disease Rating and Reaction Classes}

Based on 1-9 rating scale, rice cultivars were categorized into five groups (HR, R, MR, $S$ and HS) in accordance with their level of resistance against Tanzanian RYMV strains and phylotypes (Table 4). Significant differences were observed $(P \leq 0.05)$ between differential resistant rice cultivars on their reaction to RYMV strains and phylotypes (Table 4). The RYMV disease reaction ranged from 1 on the highly resistant rice cultivars Tog5672 and Tog5674 inoculated with all RYMV strains S4lm (Tz526), S4lv (Tz516), S4ug (Tz508), S5 (Tz429, Tz445), S6c (Tz486) and S6w (Tz539) and Tog5681 inoculated with S4lv (Tz516), S4ug (Tz508) and S6c (Tz486) to 9 on highly susceptible local rice cultivar SARO-5 inoculated with all RYMV strains and phylotypes, except S4ug (Tz508) (Table $4)$.

\subsection{The Area under Disease Progress Curve (AUDPC)}

The area under disease progress curve (AUDPC) was statistically significant difference $(P \leq 0.05)$ between resistant rice cultivars and RYMV strains and phylotypes (Figure 1). Disease development in each RYMV strain and/or phylotype progressed differently with resistant rice cultivars depending on their resistance-breaking ability. The highest AUDPC was recorded in susceptible rice cultivar SARO-5 $(631,628)$ inoculated with S5 (Tz445, Tz429) followed by resistant cultivars Tog12387 (491, 478), Tog5438 $(464,458)$ and Gigante $(333,328)$, inoculated with S5 (Tz445, Tz429), respectively. These were followed by resistant cultivars Tog12387 $(336,327,307)$ inoculated with S6w (Tz539), S4lm (Tz526) and S4lv (Tz516), Tog5438 (258) inoculated with S4lm (Tz526), Tog5681 (239, 237) inoculated with S5 (Tz445, Tz429), respectively. The lowest AUDPC were recorded in resistant rice cultivars Tog5672 (78) and Tog5674 (78) inoculated with all RYMV strains and phylotypes (S4lm, S4lv, S4ug, S5, S6c and S6w) followed by resistant rice cultivars Tog5681 (78) inoculated with S4ug (Tz508) and S6c (Tz486) and Gigante $(85,87)$ inoculated with S6c (Tz486) and S4ug (Tz508), respectively.

\subsection{Days to First Symptom Appearance on Resistant Rice Culti- vars Inoculated with RYMV Strains and Phylotypes}

Days to first appearance symptoms on resistant rice cultivars inoculated with RYMV strains and phylotypes are summarized in Table 5. Days to first appearance of symptoms varied significantly between cultivars $(P \leq 0.05)$. Symptoms on the leaves of the susceptible controls IR64 and SARO-5 were observed earlier than the resistant checks. The first symptoms were observed on rice cultivar Azucena inoculated with S5 (Tz445, Tz429), S4lm (Tz526), S6w (Tz539), S4lv (Tz516), S4ug (Tz508) and S6c (Tz486) 13, 25, 26, 30, 3438 days after inoculation (DAI), respectively. The cultivar Gigante inoculated with RYMV strains S5 (Tz445, Tz429), S4lm (Tz526) and S6w (Tz539) showed first symptoms 13, 23 and $24 \mathrm{DAI}$, respectively. The first disease symptoms were noted on Gigante and 
Table 5. Days to appearance of Rice yellow mottle virus symptoms on resistant rice cultivars.

\begin{tabular}{|c|c|c|c|c|c|c|c|c|}
\hline \multirow{2}{*}{$\begin{array}{c}\text { Rice } \\
\text { genotype }\end{array}$} & \multirow{2}{*}{$\begin{array}{l}\text { Resistant } \\
\text { gene }\end{array}$} & \multicolumn{7}{|c|}{ Days to appearance of symptoms } \\
\hline & & S4lm Tz526 & $\begin{array}{c}\text { S4lv } \\
\text { Tz516 }\end{array}$ & $\begin{array}{c}\text { S4ug } \\
\text { Tz508 }\end{array}$ & S5 Tz445 & S5 Tz429 & S6c Tz486 & $\begin{array}{c}\text { S6w } \\
\text { Tz539 }\end{array}$ \\
\hline Azucena & QTLs & 25 & 30 & 34 & 13 & 13 & 38 & 26 \\
\hline Gigante & rymvl-2 & 23 & 28 & 40 & 13 & 13 & 42 & 24 \\
\hline Tog12387 & rymvl-3 & 13 & 14 & 15 & 10 & 9 & 16 & 13 \\
\hline $\operatorname{Tog} 5438$ & rymvl-4 & 23 & 30 & 30 & 13 & 13 & 38 & 34 \\
\hline $\operatorname{Tog} 5672$ & $\begin{array}{c}r y m v 1-4+r y \\
m v 2\end{array}$ & ns & ns & ns & ns & ns & ns & ns \\
\hline $\operatorname{Tog} 5674$ & rymvl-5 & ns & ns & ns & ns & 42 & ns & ns \\
\hline Tog5681 & rymv1-3 & 35 & ns & ns & 28 & 28 & ns & 30 \\
\hline \multicolumn{9}{|l|}{ S. control } \\
\hline IR64 & rymvl-1 & 7 & 9 & 15 & 7 & 6 & 15 & 7 \\
\hline SARO-5 & Unknown & 6 & 7 & 8 & 5 & 5 & 8 & 7 \\
\hline
\end{tabular}

ns $=$ no symptoms appearance on the rice leaves, $\mathrm{S}=$ Susceptible.

Tog5681 inoculated with phylotype S4lv (Tz516) and strain S5 (Tz445, Tz429), respectively, 28 DAI. However, rice cultivar Tog5681 inoculated with S6w (Tz539) and S4lm (Tz526), first symptoms were observed 30 and 35 DAI, respectively. Symptoms of RYMV were not observed in non-inoculated controls and rice cultivar Tog5672 until maturity. The rice cultivar Tog5674 inoculated with S5 (Tz445) produced first symptoms 42 DAI (Table 5).

\subsection{Enzyme-Linked-Immunorsobent Assay Response to Rice yellow mottle virus Strains Infection of Resistant Rice Cultivars at 42 Days after Inoculation}

The titer of RYMV in resistant rice cultivars inoculated with different strains and phylotypes was measured by ELISA in order to confirm the resistance breakdown. Rice yellow mottle virus titer varied significantly $(P \leq 0.05)$ between differential resistant rice cultivars (Figure 2(a) and Figure 2(b)). Rice cultivars Azucena, Gigante, Tog12387 and Tog5438 inoculated with RYMV strains S5 (Tz445, Tz429) gave significantly higher virus titer than those inoculated with phylotypes S4lm (Tz526), S4lv (Tz516), S4ug (Tz508), S6c (Tz486) and S6w (Tz539) (Figure 2(a)-(d)). However, the highest RYMV titer was obtained in leaf extracts of rice cultivars Tog12387 inoculated with phylotypes S4lm (Tz526) and S6w (Tz539) and Tog5438 inoculated with phylotypes S4lm (Tz526) and S4lv (Tz516) (Figure 2(a)-(d)). By contrast, Tog5674 inoculated with strain S5 (Tz429, Tz445) and Tog5681 inoculated with phylotypes S4lm (Tz526) and S6w (Tz539) had the lowest virus titer. The results also revealed the presence of the virus in asymptomatic plants of Tog5674 inoculated with RYMV strain S5 (Tz445) (Figure 2(b)). 
๑S4lm (Tz526)

S4lv (Tz516)

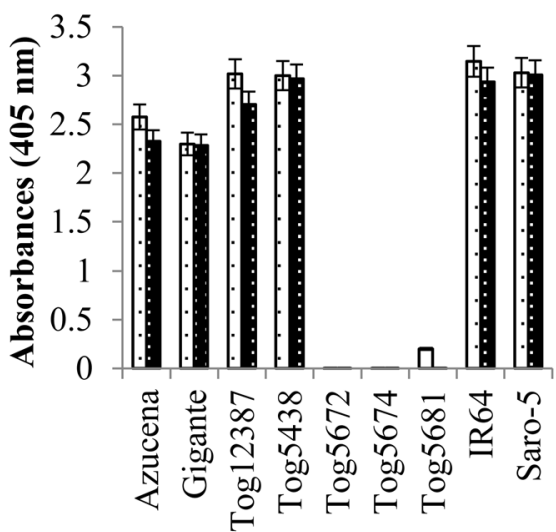

(a)

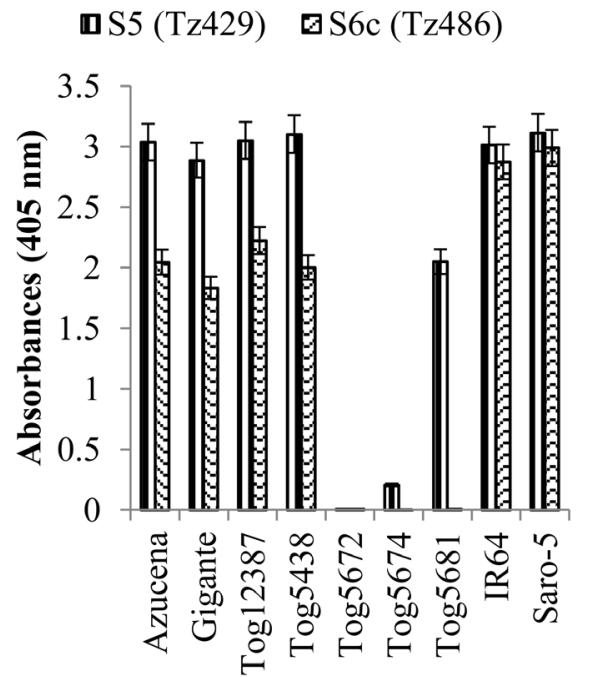

日S4ug (Tz508) $\mathbf{\Delta S 5}(\mathrm{Tz} 445)$

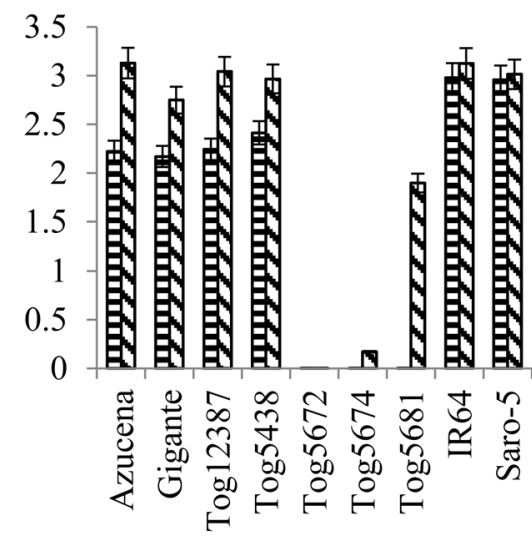

(b)

๘S6w (Tz539) घNon-i

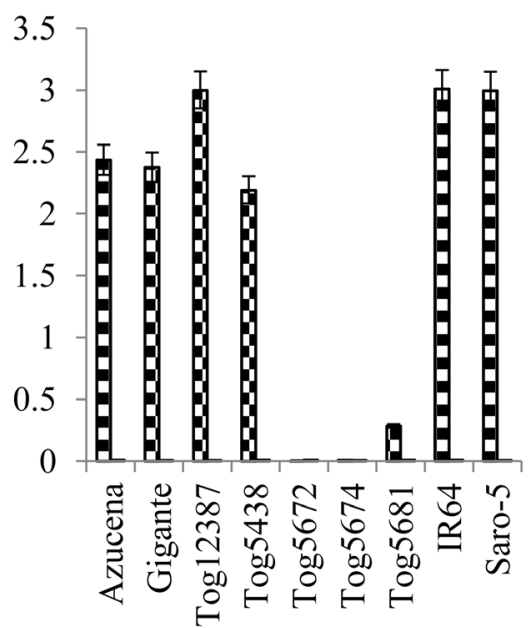
Inoculated resistant rice cultivars

(c)

(d)

Figure 2. Titer of Rice yellow mottle virus associated with resistant-breaking as evaluated through serological tests. The optical density values in ELISA were coded as positive reaction if $>2 \times$ Negative Control $>0.1$.

\subsection{Effect of Rice yellow mottle virus Strains on Yield Components of Resistant Rice cultivars}

There were highly significant differences $(P \leq 0.001)$ on performance of yield components between resistant rice cultivars inoculated with different strains and phylotypes (Table 6). The plant height of inoculated differential rice cultivars was highly significantly reduced $(P \leq 0.001)$ and varied among RYMV strains. The highest height reduction was recorded on rice cultivar Tog12387 (84.9\%) inoculated with RYMV strain S5 (Tz445) while the lowest reduction was recorded on rice cultivar Tog5674 (0.8\%) inoculated with phylotype S4ug. However, the plant height of rice cultivar Tog5674 was only affected by strain S5 (Tz445, Tz429). The RYMV strain S5, caused greater plant height reduction in most of rice cultivars except Tog5672. 
Table 6. Yield components of resistant rice cultivars inoculated with RYMV strains and phylotypes in the screen house.

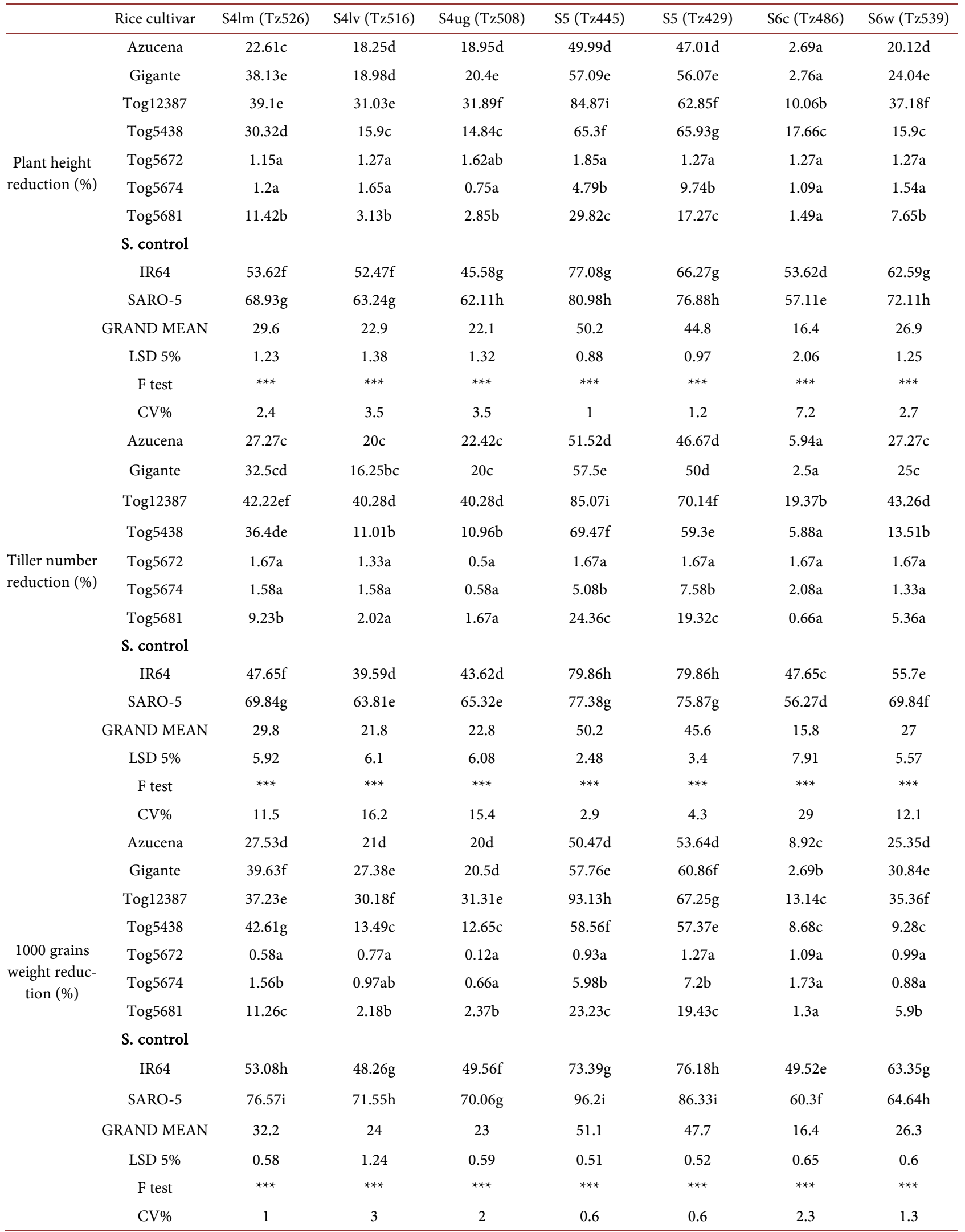

*Values are means of three replicates. Numbers followed by the same letter in a column are not significantly different at $P=0.05$, using Duncan's Multiple Range Test. ${ }^{* * *}=$ Highly significantly different $(P<0.001)$. 
Tiller production differed significantly $(P \leq 0.05)$ between inoculated differential rice cultivars (Table 6). The lowest reduction in tillering was recorded in rice cultivars Tog5672 (0.5\%) and Tog5674 (0.6\%) inoculated with RYMV phylotype S4ug while the highest tillering reduction occurred in rice cultivars Tog12387 (85.1\%) inoculated with strain S5 (Tz445). Strain S5 (Tz429, Tz445) reduced tillers on cultivar Tog 5674 by $5.1 \%$ and $7.6 \%$, respectively (Table 6 ). The resistance of cultivar Gigante was overcome by all RYMV strains and phyloypes S4lm, S4lv, S4ug, S5, S6c and S6w tested, which lead to high reduction in number of tillers. The highly resistant cultivar Tog5681 inoculated with S4lm (Tz526), S5 (Tz429, Tz445) and S6w (Tz539) overcome its resistance and reduced tillers by $9.2 \%, 24.4 \%, 19.3 \%$ and $5.4 \%$, respectively. There was no RYMV strain or phylotype which reduced tillers in cultivar Tog5672.

Reduction in 1000 grain weight of rice cultivars was highly significantly different $(P \leq 0.05)$ as influenced by RYMV strains and phylotypes except in Tog5672 (Table 6). The highest reduction in 1000 grain weight was recorded in susceptible variety SARO-5 (96.2\%) inoculated with RYMV strain S5 (Tz445). Reduction in 1000 grain weight (2.7\%) was lowest in rice cultivar Gigante inoculated with RYMV strain S6c (Tz486). In Tog5674, only rice plants inoculated with strain S5 reduced 1000 grains weight although the cultivar was asymptomatic (Table 5).

\subsection{Percentage Yield Loss of Resistant Rice Cultivars Inoculated with RYMV Strains and Phylotypes in the Screen House}

The percentage rice grain yield losses differed significantly $(P \leq 0.001)$ between the rice cultivars, strains and phylotypes (Table 7). The highest percentage yield loss was recorded on rice cultivars Tog12387 (99.1\%) and Tog5438 (81.2\%) inoculated with RYMV strain S5 (Tz445) followed by S5 (Tz429). The lowest yield losses were recorded on cultivar Tog5438 (4.3\%), Gigante (5\%), Azucena (5.8\%) inoculated with strain S6c (Tz486) and Tog5681 (6.4\%), Tog5674 (6.7\%) inoculated with S6w (Tz539) and S5 (Tz445), respectively. Only strain S5 affected yield loss per panicle on cultivar Tog5674.

\subsection{Spikelet Sterility on Resistant Rice Cultivars Inoculated with RYMV Strains and Phylotypes in the Screenhouse}

Spikelet sterility differed significantly $(P \leq 0.05)$ between inoculated differential rice cultivars (Table 8 ). Percentage spikelet sterility of non-inoculated rice cultivars did not statistically differ significantly at $5 \%$ level. The highest spikelet sterility was recorded on rice cultivars Tog12387 and Tog5438 inoculated with S5 (Tz429, Tz445). The lowest spikelet sterility was recorded on rice cultivars Azucena, Gigante and Tog5438 inoculated with S6c (Tz486), Tog5674 inoculated with S5 (Tz429, Tz445) and Tog5681 inoculated with S6w (Tz539). By contrast, only strain S5 caused spikelet sterility on cultivar Tog5674. Significantly ( $P$ $\leq 0.001$ ), inoculated plants had higher percentages of spikelet sterility than non-inoculated plants (Table 8). Rice cultivars Tog5674 and Tog5681 inoculated 
Table 7. Effect of RYMV strains and phylotypes on the yield per panicle in resistant rice cultivars grown under screen house conditions.

\begin{tabular}{|c|c|c|c|c|c|c|c|}
\hline \multirow[b]{2}{*}{ Rice cultivar } & \multicolumn{7}{|c|}{ Yield loss per panicle (\%) } \\
\hline & $\begin{array}{c}\text { S4lm } \\
(\mathrm{Tz} 526)\end{array}$ & $\begin{array}{c}\text { S4lv } \\
(\mathrm{Tz} 516)\end{array}$ & $\begin{array}{c}\text { S4ug } \\
\text { (Tz508) }\end{array}$ & $\begin{array}{c}\text { S5 } \\
(\mathrm{Tz} 445)\end{array}$ & $\begin{array}{c}\text { S5 } \\
(\mathrm{Tz} 429)\end{array}$ & S6c $(\mathrm{Tz} 486)$ & S6w (Tz539) \\
\hline Azucena & $37 c$ & $25.8 \mathrm{c}$ & $20.4 \mathrm{~d}$ & $52.7 \mathrm{~d}$ & $49.7 \mathrm{~d}$ & $5.8 \mathrm{~b}$ & $38.1 \mathrm{~d}$ \\
\hline Gigante & $38.2 \mathrm{c}$ & $28.8 \mathrm{~d}$ & $15.6 \mathrm{c}$ & $56.5 \mathrm{e}$ & $61.8 \mathrm{e}$ & $5 b$ & $37.1 \mathrm{~d}$ \\
\hline $\operatorname{Tog} 12387$ & $57.5 \mathrm{~d}$ & $40.6 \mathrm{e}$ & $39.1 \mathrm{e}$ & $99.1 \mathrm{~h}$ & $77.9 \mathrm{~g}$ & $20.9 c$ & $52.8 \mathrm{e}$ \\
\hline $\operatorname{Tog} 5438$ & $36.4 \mathrm{c}$ & $9.8 \mathrm{~b}$ & $8.7 \mathrm{~b}$ & $81.2 \mathrm{f}$ & $73 \mathrm{f}$ & $4.3 \mathrm{ab}$ & $22.4 \mathrm{c}$ \\
\hline $\operatorname{Tog} 5672$ & $1.9 \mathrm{a}$ & $1.4 \mathrm{a}$ & $1 \mathrm{a}$ & $2 \mathrm{a}$ & $1.2 \mathrm{a}$ & $1.1 \mathrm{a}$ & $1.1 \mathrm{a}$ \\
\hline $\operatorname{Tog} 5674$ & $1.9 \mathrm{a}$ & $1.5 \mathrm{a}$ & $0.1 \mathrm{a}$ & $6.7 \mathrm{~b}$ & $11.6 \mathrm{~b}$ & $1.7 \mathrm{a}$ & $1.2 \mathrm{a}$ \\
\hline $\operatorname{Tog} 5681$ & $20.7 b$ & $2.2 \mathrm{a}$ & $2.6 \mathrm{a}$ & $28.9 \mathrm{c}$ & $29.7 \mathrm{c}$ & $1.8 \mathrm{a}$ & $6.4 \mathrm{~b}$ \\
\hline \multicolumn{8}{|l|}{ S. control } \\
\hline IR64 & $63.3 \mathrm{e}$ & $58.2 \mathrm{f}$ & $55.8 \mathrm{f}$ & $93.8 \mathrm{~g}$ & $95.7 \mathrm{~h}$ & $52.2 \mathrm{~d}$ & $66.8 \mathrm{f}$ \\
\hline SARO-5 & $76.4 \mathrm{f}$ & $70.6 \mathrm{~g}$ & $69.3 \mathrm{~g}$ & $98.9 \mathrm{~h}$ & $95.7 \mathrm{~h}$ & $62.1 \mathrm{e}$ & $71 \mathrm{~g}$ \\
\hline $\begin{array}{l}\text { GRAND } \\
\text { MEAN }\end{array}$ & 37 & 26.6 & 23.6 & 59.8 & 55.1 & 17.2 & 33 \\
\hline LSD 5\% & 3.09 & 2.82 & 3.85 & 2.54 & 2.31 & 3.04 & 2.65 \\
\hline$F$ test & $* * *$ & $* * *$ & $* * *$ & $* * *$ & $* * *$ & $* * *$ & $* * *$ \\
\hline $\mathrm{CV} \%$ & 4.8 & 6.1 & 9.4 & 2.5 & 2.4 & 10.2 & 4.6 \\
\hline
\end{tabular}

*Values are means of three replicates. Numbers followed by the same letter in a column are not significantly different at $P=0.05$, using Duncan's Multiple Range Test. ${ }^{* *}=$ Highly significantly different $(P<0.001)$.

Table 8. Spikelet sterility of resistant rice cultivars as influenced by RYMV strains and their phylotypes under screen house condition.

\begin{tabular}{|c|c|c|c|c|c|c|c|c|}
\hline \multirow[b]{2}{*}{ Rice cultivar } & \multicolumn{8}{|c|}{ Spikelet sterility (\%) } \\
\hline & $\begin{array}{c}\text { S4lm } \\
(\text { Tzz526) }\end{array}$ & $\begin{array}{c}\text { S4lv } \\
(\text { Tz516) }\end{array}$ & $\begin{array}{c}\text { S4ug } \\
\text { (Tz508) }\end{array}$ & S5 (Tz445) & S5 (Tz429) & $\begin{array}{c}\text { S6c } \\
(\mathrm{Tz} 486)\end{array}$ & $\begin{array}{c}\text { S6w } \\
\text { (Tz539) }\end{array}$ & Non-i \\
\hline Azucena & $25.01 \mathrm{e}$ & $17.11 \mathrm{~d}$ & $21.03 \mathrm{e}$ & $49.84 \mathrm{~d}$ & $53.98 \mathrm{~d}$ & $4.26 \mathrm{c}$ & $26.28 \mathrm{~d}$ & $0.27 \mathrm{a}$ \\
\hline Gigante & $29.61 \mathrm{f}$ & $27.36 \mathrm{e}$ & $18.92 d$ & $57.95 \mathrm{e}$ & $60.42 \mathrm{e}$ & $3.52 \mathrm{c}$ & $33.53 \mathrm{e}$ & $1.12 \mathrm{abc}$ \\
\hline Tog12387 & $44.31 \mathrm{~g}$ & $33.81 \mathrm{f}$ & $25.44 \mathrm{f}$ & $99.63 \mathrm{~h}$ & $79.75 \mathrm{~g}$ & $13.4 \mathrm{e}$ & $40.4 \mathrm{f}$ & $0.94 \mathrm{abc}$ \\
\hline Tog5438 & $20 \mathrm{~d}$ & $12.58 \mathrm{c}$ & $13.63 c$ & $63.39 \mathrm{f}$ & $62.11 \mathrm{f}$ & $7.57 \mathrm{~d}$ & $16.21 \mathrm{c}$ & $1.01 \mathrm{abc}$ \\
\hline Tog5672 & $0.69 \mathrm{a}$ & $0.7 \mathrm{a}$ & $0.21 \mathrm{a}$ & $0.89 \mathrm{a}$ & $0.85 \mathrm{a}$ & $1.3 \mathrm{a}$ & $1.01 \mathrm{a}$ & $1.03 \mathrm{abc}$ \\
\hline $\operatorname{Tog} 5674$ & $2.54 \mathrm{~b}$ & $2.05 b$ & $0.67 \mathrm{a}$ & $5.5 b$ & $8.25 b$ & $2.49 \mathrm{~b}$ & $1.59 \mathrm{a}$ & $1.57 \mathrm{bc}$ \\
\hline $\operatorname{Tog} 5681$ & $10.57 \mathrm{c}$ & $1.85 \mathrm{~b}$ & $2.01 \mathrm{~b}$ & $23.75 c$ & $14.61 \mathrm{c}$ & $0.95 a$ & $5.18 \mathrm{~b}$ & $1.81 \mathrm{c}$ \\
\hline \multicolumn{9}{|l|}{ S. control } \\
\hline IR64 & $55.47 \mathrm{~h}$ & $39.18 \mathrm{~g}$ & $43.29 \mathrm{~g}$ & $75.63 \mathrm{~g}$ & $85.72 \mathrm{i}$ & $49.74 \mathrm{f}$ & $61.56 \mathrm{~g}$ & $0.98 \mathrm{abc}$ \\
\hline SARO-5 & $76.17 \mathrm{i}$ & $67.18 \mathrm{~h}$ & $68.34 \mathrm{~h}$ & $99.68 \mathrm{~h}$ & $83.05 \mathrm{~h}$ & $56.5 \mathrm{~g}$ & $75.29 \mathrm{~h}$ & $0.59 \mathrm{ab}$ \\
\hline $\begin{array}{l}\text { GRAND } \\
\text { MEAN }\end{array}$ & 29.37 & 22.42 & 21.5 & 52.92 & 49.86 & 15.53 & 29.01 & 1.04 \\
\hline LSD 5\% & 0.94 & 0.746 & 0.818 & 0.447 & 0.456 & 0.814 & 0.854 & 1.012 \\
\hline $\mathrm{F}$ test & $* * *$ & $* * *$ & $* * *$ & $* * *$ & $* * *$ & $* * *$ & $* * *$ & * \\
\hline CV\% & 1.8 & 1.9 & 2.2 & 0.5 & 0.5 & 3 & 1.7 & 56.5 \\
\hline
\end{tabular}

*Values are means of three replicates. Numbers followed by the same letter in a column are not significantly different at the $5 \%$ probability level by the Duncan's Multiple Range Test. ${ }^{* *}=$ Highly significantly different $(P<0.001),{ }^{*}=$ Significantly different $(P<0.01)$, Non- $\mathrm{i}=$ Non-inoculated, $\mathrm{S}=$ Susceptible. 
with RYMV phylotypes S4lv (Tz516), S4ug (Tz508) and S6c (Tz486) had similar spikelet sterility to non-inoculated plants (healthy controls).

\section{Discussion}

Great pathogenic variation of Tanzanian RYMV strains was detected in resistance breakdown of the rice cultivars with one resistant gene ( $R Y M V 1)$. Emergence of new pathogen strains through genetic mutation and recombination may result to virulent strains which are capable for overcoming the resistance of commercial rice varieties used in crop production world-wide. The resistance breaking of cultivars carrying rymvl resistant allele has been studied and genetic determinants established [40]. Multiple resistance-breaking was evident on resistant cultivars Gigante, Tog12387, Tog5438 and Tog5681 overcome by all strains except S4lv (Tz516), S4ug (Tz508) and S6c (Tz486) on cultivar Tog5681. Phylotypes S4lv, S4ug and S6c are widely distributed in Coast, Eastern and Southern rice growing regions in Tanzania causing a major rice production constraint [17]. However, rice cultivar Tog5681 could be a good source of resistance to RYMV in these areas.

The rice cultivar Tog12387 was reported by Jaw [6] as resistant to the West African RYMV strains, but it was susceptible to all Tanzanian RYMV strains suggesting existence of differences RYMV virulent pathotypes. In this study rice cultivar Tog5672 showed resistance to all RYMV strains while rice cultivar Tog5674 to RYMV phylotypes S4lm (Tz526), S4lv (Tz516), S4ug (Tz508), S6c (Tz486) and S6w (Tz539) followed by Tog5681 being resistant to S4lv (Tz516), S4ug (Tz508) and S6c (Tz486) phylotypes. The most virulent strain was S5 (Tz429, Tz445) that overcome almost all resistant cultivars tested, except Tog5672. This could be due to specific biological features of strain S5. Strain S5 is the most prevalent and virulent strain causing severe yield losses in Northern Morogoro including Kilombero Valley [16]. However, rice cultivar Tog5672 provides a good source of resistance to strain S5 which is likely in the future to spread in other areas through long distance insect vectors transmission. The virulent level of phylotype S4lm (Tz526) was close to strain S6w (Tz539) which also show similar reactions in resistance breakdown. Resistant-breaking strains that were capable of overcoming the highly resistance in rice cultivars such as Gigante, Tog5674 and Tog5681 could be associated with RYMV strain recombination traits [41].

The stable resistance in rice cultivar Tog5672 to Tanzanian RYMV strains and phylotypes observed in this study could be due to the presence of its second resistance gene on $R Y M V 2$ locus [4] [7]. Ndjiondjop et al. [42] observed that the high resistance in rice cultivars Tog5681 (O. glaberrima) and Gigante (O. sativa) to RYMV was not due to inhibition of virus replication but rather to the failure of cell to cell movement of the virus. West and Central African RYMV strains S1 and S2 overcome the resistance in rice cultivar Gigante (rymvl-2) and in Tog5681 (rymvl-3) [24] [26] [29]. However, the stable resistance of rice cultivar Tog5672 could be utilized towards breeding through introgression of resistance 
genes in Tanzania susceptible rice cultivars to RYMV.

Days to RYMV symptoms appearance varied significantly $(P \leq 0.05)$ between inoculated cultivars. However, assessment of resistant rice cultivars by symptoms is not enough to determine the virulence of the virus as some cultivars had genotypic features of hiding symptoms [43] despite high virus titer. Phenotypic expression of resistance in rice cultivar Tog5672 was also confirmed quantitatively having very low titer values by ELISA in this study. However, ELISA results indicated that Tog5674 and Tog5681 were resistant to RYMV phylotypes S4lv (Tz516), S4ug (Tz508) and S6c (Tz486) with low virus content and susceptible to S5 (Tz429, Tz445) with high virus titer suggesting that resistant breaking could be associated with viral multiplication rates. Rice yellow mottle virus strain S5 (Tz445) multiplied in resistant rice cultivar Tog5674 without inducing symptoms but showed detectable virus titer in ELISA. The delayed appearance of the typical symptoms on rice cultivars might be due to their genetic make-up as some cultivars showed latent infection. This phenomenon has also been reported to be associated with $R Y M V 1$ resistance gene [42]. However, the $R Y M V 1$ resistance from the phenotyping was also opposed in detection of virus titer by quantitative reverse transcriptase-polymerase chain reaction [24].

Breeding for resistance is widely focused by researchers as the key strategy for RYMV disease control [3] [6] [7] [9] [30]. The development of rice cultivars resistant to RYMV disease is strongly supported in rice breeding programs and some highly resistant varieties such Bekarosaka have been released in Madagascar [44]. However, resistance breakdown [26] in rice plant due to existence of virulent virus strains can cause the resistance redundant that could affect crop production. The resistant breaking RYMV strains also reduced plant height, tillers and 1000 grains weight as well as spikelet sterility, cause yield losses. Efforts should be done towards selection of genotypes with stable resistance to minimize yield losses that farmers likely to incur. However, the stress caused by RYMV had less impact to the yield components of rice cultivar Tog5674 as compared to other rice cultivars suggesting that the mechanisms for overcoming high resistance are different in nature. Rice yield based on the number of tillers per plant was probably due to aggressiveness of RYMV strain that infected rice plant at minimum tillering stage. Furthermore, variability in spikelet sterility in RYMV strains-inoculated rice cultivars might have been contributed by the effect of different level of infection by RYMV strains during the grain filling stage. The breeding programs should therefore consider virus variability and the emergence of resistance-breaking strains [16].

The capability of RYMV to overcome RYMV resistance gene at molecular level has been studied [1] [25] [45] and was associated with virus characteristics found in the viral protein genome-linked [41]. Furthermore, the genetic barrier to virulence was identified in human being and compared with viral drug resistance [46]. This was also determined between RYMV strains S1, S4 and S6 obtained from Savannah, Madagascar and Tanzania, respectively, as an inclination for the virus to overcome the rymvl-2 resistance by developing virulence muta- 
tions [23]. Pathogenic variation was observed among the isolates tested in which strain S4 (Mg 16) obtained from northwest of Madagascar overcame rymvl-2 resistance at high rate [23]. Detailed studies reported here provide understanding of virulence levels of Tanzanian RYMV strains and phylotypes and their reaction to genotypes with known resistant genes hence provide access to the selection of appropriate resistant genotypes for various locations and for improvement of local varieties in rice future breeding programs.

\section{Conclusions}

The ability of Tanzanian RYMV strains and phylotypes to overcome resistance conferred by $R Y M V 1$ gene was determined. However, the analysis on molecular basis of resistance breakdown is recommended based on identification of RB mutations by sequencing of the RYMV genome in infected rice cultivars and mutagenesis of an infectious viral clone. The results indicate that $R Y M V l$ gene resistance breakdown was highly variable depending on the strain used, and disease severity ranged from $11 \%-75.3 \%$. Rice yellow mottle virus pathogen caused significant yield losses ranging from $5 \%-99 \%$ in resistant rice cultivars depending on the RYMV strain used. This study also showed that, multiple resistant-breaking occurred in resistant rice cultivars Gigante (rymvl-2), Tog12387 (rymv1-3), Tog5681 (rymv1-3), Tog5438 (rymv1-4) inoculated with RYMV strains S4lm, S4lv, S4ug, S5, S6c and S6w. However, resistant-breaking did not occur in rice cultivar Tog5681 inoculated with RYMV phylotypes S4lv, S4ug and S6c. Therefore, rice cultivar Tog5681 could be a good source of resistance in areas where S4lv, S4ug and S6c are widely distributed. The results indicate high capacity of RYMV strain S5 to overcome rymv1-2, rymv1-3, rymv1-4 and rymv1-5 resistance that may be due specific features of strain S5 biology, thus, calls for the study on interaction between rice cultivars and survival of S5. Further research is also needed to determine alleles that may be resistant against RYMV strain S5.

Rice cultivar Tog5672 with allele rymv1-4 + rymv2 remained effective against Tanzanian RYMV strains and phylotypes used in this study. Based on these findings, the rice cultivar Tog5672 might have resistance durability factors that should be further studied and directed towards breeding to introgression of such resistance in susceptible rice cultivars to RYMV prevalent in Tanzania. The development of resistant rice cultivars must take into account variability of RYMV strains in targeted areas. Better understanding of the factors that favor the emergence of pathogen virulence is essential for planning strategies for breeding and the use of resistance that will result in durable protection. Furthermore, the continued screening for resistance of rice cultivars to RYMV is recommended in order to identify the resistance controlled by multiple genes but also with highly durable resistance.

\section{Acknowledgements}

We thank the Innovative Agricultural Research Initiative (iAGRI) for providing 
funds for this work. Thanks are due to Institut de Recherche pour le Developement (IRD), France, AfricaRice and Sokoine University of Agriculture (SUA), Tanzania for supplying rice plant genotypes and providing research facilities.

\section{References}

[1] Traoré, O., Galzi-Pinel, A., Poulicard, N., Hébrard, E., Konaté, G. and Fargette, D. (2008) Rice Yellow Mottle Virus Diversification Impact on the Genetic Control of RYMV. Journal of Plant Disease, 5, 1-4.

[2] Pidon, H., Ghesquière, A., Chéron, S., Issaka, S., Hébrard, E., Sabot, F., Kolade, O., Silué, D. and Albar, L. (2017) Fine Mapping of RYMV3: A New Resistance Gene to Rice Yellow Mottle Virus from Oryza glaberrima. Theoretical and Applied Genetics, 130, 807-818. https://doi.org/10.1007/s00122-017-2853-0

[3] Ndjiondjop, M.N., Albar, L., Fargette, D., Fauquet, C. and Ghesquière, A. (1999) The Genetic Basis of High Resistance to Rice Yellow Mottle Virus (RYMV) in Cultivars of Two Cultivated Rice Species. Journal of Plant Disease, 83, 931-935. https://doi.org/10.1094/PDIS.1999.83.10.931

[4] Albar, L., Ndjiondjop, M., Esshak, Z., Berger, A., Pinel, A., Jones, M., Fargette, D. and Ghesquière, A. (2003) Fine Mapping of a Gene Required for Rice Yellow Mottle Virus Cell-to-Cell Movement. Theoretical Applied Genetics, 107, 371-378. https://doi.org/10.1007/s00122-003-1258-4

[5] Albar, L., Bangratz-Reyser, M., Hebrard, E., Ndjiondjop, M., Jones, M. and Ghesquière, A. (2006) Mutations in the eIF(iso)4G Translation Initiation Factor Confer High Resistance to Rice Yellow Mottle Virus. The Plant Journal, 47, 417-426. https://doi.org/10.1111/j.1365-313X.2006.02792.x

[6] Jaw, A. (2010) Screening and Molecular Characterization of Near-Isogenic Lines for Resistance to Rice Yellow Mottle Virus. Thesis for Award of PhD Degree, Kwame Nkrumah University of Science and Technology, Kumasi, 31-42.

[7] Thiémélé, D., Boisnard, A., Ndjiondjop, M.N., Chéron, S., Séré, Y., Aké, S., Ghesquière, A. and Albar, L. (2010) Identification of a Second Major Resistance Gene to Rice Yellow Mottle Virus, RYMV2, in the African Cultivated Rice Species, O. glaberrima. Journal of Theoretical and Applied Genetics, 121, 169-179.

https://doi.org/10.1007/s00122-010-1300-2

[8] Pinel-Galzi, A., Dubreuil-Tranchant, C., Hébrard, E., Mariac, C., Ghesquière, A. and Albar, L. (2016) Mutations in Rice Yellow Mottle Virus Polyprotein P2a Involved in RYMV2 Gene Resistance Breakdown. Frontiers in Plant Science, 7, 1779. https://doi.org/10.3389/fpls.2016.01779

[9] Albar, L., Lorieux, M., Ahmadi, N., Rimbault, I., Pinel, A., Sy, A., Fargette, D. and Ghesquière, A. (1998) Genetic Basis and Mapping of the Resistance to Rice Yellow Mottle Virus. I. QTLs Identification and Relationship between Resistance and Plant Morphology. Theoretical and Applied Genetics, 97, 114-1154. https://doi.org/10.1007/s001220051003

[10] Ghesquière, A., Albar, L., Lorieux, M., Ahmadi, N., Fargette, D., Huang, N., McCouch, S.R. and Notteghem, J.L. (1997) A Major Quantitative Trait Locus for Rice Yellow Mottle Virus Resistance Maps to a Cluster of Blast Resistance Genes on Chromosome 12. Phytopathology, 87, 1243-1249. https://doi.org/10.1094/PHYTO.1997.87.12.1243

[11] Ribeiro Do Vale, F.X., Parlevliet, J.E. and Zambolim, L. (2001) Concepts in Plant Disease Resistance. Fitopatologia Brasileira, 26, 577-589.

https://doi.org/10.1590/S0100-41582001000300001 
[12] Kouassi, N.K., N'Guessan, P., Albar, L., Fauquet, C.M. and Brugidou, C. (2005) Distribution and Characterization of Rice Yellow Mottle Virus. A Threat to African Farmers. Journal of Plant Disease, 89, 124-133. https://doi.org/10.1094/PD-89-0124

[13] Pinel, A., N’Guessan, P., Bousalem, M. and Fargette, D. (2000) Molecular Variability of Geographically Distinct Isolates of Rice Yellow Mottle Virus in Africa. Archives of Virology, 145, 1621-1638. https://doi.org/10.1007/s007050070080

[14] Abubakar, Z., Ali, F., Pinel, A., Traoré, O., N’Guessan, P., Notteghem, J., Kimmins, F., Konaté, G. and Fargette, D. (2003) Phylogeography of Rice Yellow Mottle Virus in Africa. Journal of General Virology, 84, 733-743. https://doi.org/10.1099/vir.0.18759-0

[15] Banwo, O.O., Alegbejo, M.D. and Abo, M.E. (2004) Rice Yellow Mottle Virus Genus Sobemovirus: A Continental Problem in Africa. Journal of Plant Protection Science, 40, 26-36.

[16] Kanyeka, Z.L., Sangu, E., Fargette, D., Pinel-Galzi, A. and Hébrard, E. (2007) Distribution and Diversity of Local Strains of Rice Yellow Mottle Virus in Tanzania. African Journal of Crop Science, 15, 201-209.

[17] Hubert, J., Lyimo, H.J.F. and Luzi-Kihupi, A. (2017) Geographical Variation, Distribution and Diversity of Rice Yellow Mottle Virus Phylotypes in Tanzania. American Journal of Plant Sciences, 8, 1264-1284.

[18] Food and Agriculture Organization (2015) The Rice Value Chain in Tanzania. In: Wilson, R.T. and Lewis, I., Eds., A Report from the Southern Highlands Food Systems Programme, FAO, Tanzania, $9 \mathrm{p}$.

[19] Mghase, J.J., Shiwachi, H., Nakasone, K. and Takahashi, H. (2010) Agronomic and Socio-Economic Constraints to High Yield Of Upland Rice in Tanzania. African Journal of Agriculture Research, 5, 150-158.

[20] Kilimo-Trust (2012) Expanding Rice Markets in the EAC: An Opportunity for Actors in the Value Chain. $45 \mathrm{p}$.

[21] Lamo, L., Cho, G., Jane, I., Dartey, P.K.A., James, E., Ekobu, M., Alibu, S., Okanya, S., Oloka, B., Otim, M., Asea, G. and Kang, K. (2015) Developing Lowland Rice Germplasm with Resistance to Multiple Biotic Stresses through Anther Culture in Uganda. Journal of the Korean Society of International Agricultue, 27, 415-420. https://doi.org/10.12719/KSIA.2015.27.4.415

[22] Hubert, J., Luzi-Kihupi, A., Hébrard, E and Lyimo, H.J.F. (2016) Farmers' Knowledge and Perceptions of Rice Yellow Mottle Virus in Selected Rice Growing Areas in Tanzania. International Journal of Science and Research, 5, 549-559.

[23] Pinel-Galzi, A., Rakotomalala, M., Sangu, E., Sorho, F., Kanyeka, Z., Traoré, O., Sérémé, D., Poulicard, N., Rabenantoandro, Y., Séré, Y., Konaté, G., Ghesquière, A., Hébrard, E. and Fargette, D. (2007) Theme and Variations in the Evolutionary Pathways to Virulence of an RNA Plant Virus Species. PLoS Pathogens, 3, e180. https://doi.org/10.1371/journal.ppat.0030180

[24] Poulicard, N., Pinel-Galzi, A., Hebrard, E. and Fargette, D. (2010) Why Rice Yellow Mottle Virus Is Not Efficient at Breaking rymv1-2 Resistance. Molecular Plant Pathology, 11, 145-154. https://doi.org/10.1111/j.1364-3703.2009.00582.x

[25] Fargette, D., Pinel, A., Traoré, O., Ghesquière, A. and Konaté, G. (2002) Emergence of Resistance-Breaking Isolates of Rice Yellow Mottle Virus during Serial Inoculations. European Journal of Plant Pathology, 108, 585-591.

https://doi.org/10.1023/A:1019952907105

[26] Traoré, O., Pinel, A., Hébrard, E., Gumedzoé, M.Y.D., Fargette, D., Traoré, A.S. and Konaté, G. (2006) Occurrence of Resistance-Breaking Isolates of Rice Yellow Mottle Virus in West and Central Africa. Journal of Plant Disease, 90, 259-263. 
https://doi.org/10.1094/PD-90-0259

[27] Munganyinka, E., Edema, R., Lamo, J. and Gibson, P. (2016) The Reaction of Intraspecific and Interspecific Rice Cultivars for Resistance to Rice Yellow Mottle Virus Disease. European Journal of Experimental Biology, 6, 13-18.

[28] Sorho, F., Pinel, A., Traoré, O., Bersoult, A., Ghesquière, A., Hébrard, E., Konaté, G., Séré, Y. and Fargette, D. (2005) Durability of Natural and Transgenic Resistances in Rice to Rice Yellow Mottle Virus. European Journal of Plant Pathology, 112, 349-359. https://doi.org/10.1007/s10658-005-6607-5

[29] Amancho, N.A., Kouassi, N.K., Diallo, H.A., Bouet, A., Sangaré, A. and Kouadio, J.Y. (2009) Report of High Resistance-Breaking Isolates of Rice Yellow Mottle Virus in Cote d'Ivoire. The African Journal of Plant Science and Biotechnology, 3, 44-50.

[30] Rakotomalala, M., Pinel-Galzi, A., Albar, L., Ghesquière, A., Rabenantoandro, Y., Ramavovololona, P. and Fargette, D. (2008) Resistance to Rice Yellow Mottle Virus in Rice Germplasm in Madagascar. European Journal of Plant Pathology, 122, 277 286. https://doi.org/10.1007/s10658-008-9282-5

[31] Sow, M.E. (2012) Genetic Diversity of Oryza Species in Niger; Screening and Breeding for Resistance to Rice Yellow Mottle Virus (RYMV). PhD Thesis in Plant Breeding, University of KwaZulu-Natal, Republic of South Africa.

[32] Kam, H. Laing, M.D., Séré, Y. Thiémélé, D. Ghesquière, A. Ahmadi, N. and Ndjiondjop, M.N. (2013) Evaluation of a Collection of Rice Landraces from Burkina Faso for Resistance or Tolerance to Rice Yellow Mottle Virus. Journal of Plant Pathology, 95, 485-492.

[33] Msomba, S.W., Penza, A.H., Kibanda, J.M., Tusekelege, A., Mkuya, M., Mbapila, J.C. and Kanyeka Z.L. (2002) Proposal for Release of an Improved Aromatic High Yielding Rice Variety TXD 306 (SARO 5). Paper presented at the National Variety Release Sub-Committee and National Seed Production Committee, Selian, Arusha, Tanzania, 27-28 November 2002.

[34] International Rice Research Institute, Eds. (2002) Standard Evaluation System for Rice. 3rd Edition, Inger. Genetic Resources Center, IRRI, Los Banos, Laguna, Philippines, $23 \mathrm{p}$.

[35] Zouzou, M., Kouakou, T.H., Kone, M. and Issaka, S. (2008) Screening Rice (Oryza sativa L.) Varieties for Resistance to Rice Yellow Mottle Virus. Scientific Research and Essay, 3, 416-424.

[36] Finninsa, C. (2003) Relationship between Common Bacterial Blight Severity and Bean Yield Loss in Pure Stand and Bean-Maize Intercropping System. International Journal of Pest Management, 49, 177-185. https://doi.org/10.1080/0967087021000049269

[37] Salaudeen, M.T. (2014) Relative Resistance to Rice Yellow Mottle Virus in Rice. Plant Protection Science, 50, 1-7.

[38] William, H.A., Darrell, J.C. and Girish, B. (1990) Use of the Arcsine and Square Root Transformations for Subjectively Determined Percentage Data. Journal of Weed Science, 38, 452-458.

[39] McDonald, J.H. (2014) Biological Statistics. Data Transformation. http://www.biostathandbook.com/transformation.html

[40] Poulicard, N., Pinel-Galzi, A., Traoré, O., Vignols, F., Ghesquière, A., Konaté, G., Hébrard, E. and Fargette, D. (2012) Historical Contingencies Modulate the Adaptability of Rice Yellow Mottle Virus. PLoS Pathogens, 8, e1002482. https://doi.org/10.1371/journal.ppat.1002482

[41] Hébrard, E., Pinel-Galzi, A., Bersoult, A., Siré, C. and Fargette, D. (2006) Emer- 
gence of a Resistance-Breaking Isolate of Rice Yellow Mottle Virus during Serial Inoculations Is Due to a Single Substitution in the Genome-Linked Viral Protein VPg. Journal of General Virology, 87, 1369-1373.

https://doi.org/10.1099/vir.0.81659-0

[42] Ndjiondjop, M.N., Brugidou, C., Zang, S., Fargette, A., Ghesquire, A. and Fauquet, C. (2001) High Resistance to RYMV in Two Cultivated Rice Cultivars Is Correlated with Failure of Cell to Cell Movement. Physiological and Molecular Plant Pathology, 59, 309-316.

[43] N'guessan, P., Pinel, A., Sy, A.A., Ghesquiere, A. and Fargette, D. (2001) Distribution, Pathogenicity, and Interactions of Two Strains of Rice Yellow Mottle Virus in Forested and Savannah Zones of West Africa. Journal of Plant Disease, 85, 59-64. https://doi.org/10.1094/PDIS.2001.85.1.59

[44] Albar, L., Rakotomalala, M., Fargette, D. and Ghesquière, A. (2007) Molecular Characterization of Resistance to Rice Yellow Mottle Virus in Bekarosaka, an Indica Variety from Madagascar. Rice Genetic News, 23, 84-88.

[45] Hébrard, E., Pinel-Galzi, A. and Fargette, D. (2008) Virulence Domain of the RYMV Genome-Linked Viral Protein VPg towards Rice rymv1-2-Mediated Resistance. Archives of Virology, 153, 1161-1164. https://doi.org/10.1007/s00705-008-0087-9

[46] Beerenwinkel, N., Daumer, M., Sing, T., Rahnenfuhrer, J., Lengauer, T., Selbig, J., Hoffmann, D. and Kaiser, R. (2005) Estimating HIV Evolutionary Pathways and the Genetic Barrier to Drug Resistance. Journal of Infectious Disease, 191, 1953-1960. https://doi.org/10.1086/430005

\section{Submit or recommend next manuscript to SCIRP and we will provide best service for you:}

Accepting pre-submission inquiries through Email, Facebook, LinkedIn, Twitter, etc. A wide selection of journals (inclusive of 9 subjects, more than 200 journals)

Providing 24-hour high-quality service

User-friendly online submission system

Fair and swift peer-review system

Efficient typesetting and proofreading procedure

Display of the result of downloads and visits, as well as the number of cited articles

Maximum dissemination of your research work

Submit your manuscript at: http://papersubmission.scirp.org/

Or contact ajps@scirp.org 